Portland State University

PDXScholar

$11-1973$

\title{
Lead Content of Hair of Urban and Rural Populations of Small Animals
}

Richard Brian Raymond

Portland State University

Follow this and additional works at: https://pdxscholar.library.pdx.edu/open_access_etds

Part of the Biology Commons

Let us know how access to this document benefits you.

\section{Recommended Citation}

Raymond, Richard Brian, "Lead Content of Hair of Urban and Rural Populations of Small Animals" (1973). Dissertations and Theses. Paper 1584.

https://doi.org/10.15760/etd.1583

This Thesis is brought to you for free and open access. It has been accepted for inclusion in Dissertations and Theses by an authorized administrator of PDXScholar. Please contact us if we can make this document more accessible: pdxscholar@pdx.edu. 
AN ABSTRACT OF THE THESIS OF Richard Brian Raymond for the Master of Science in Biology presented November 19, 1973.

Title: Lead Content of Hair of Urban and Rural Populations of Small Animals.

APPROVED BY MEMBERS OF THE THESTS COMMITTEE:

Richard B. Forbes, Chairman

Richard R. Petersen

Q. D. Clarkson

Hair from small mammals of roadside, urban parkland, wilderness, and antique populations was analyzed for lead by atomic absorption spectrophotowetry. Hair from roadside populations had a significantly greater amount of lead than hair from the cther groups. Hair from antique populations did not differ in lead content from that of current populations which are removed from immediate exposure to automotive exhausts. 
LEAD CONTENT OF HAIR OF URBAN AND RURAL

POPULATIONS OF SMALL MAMMALS

by
RICHARD BRIAN RAYMOND

A thesis submitted in partial fulfillment of the

requirements for the degree of

\author{
MASTER OF SCIENCE \\ in \\ BTOLOGY
}

Poriland State Jniversity

1973 
TO THE OFFICE OF GRADUATE STUDIES AND RESEARCH:

The members of the Committee approve the thesis of Richard Brian

Raymond presented 19 November 1973.

Richard B. Forbes, Chairman

Richard R. Petersen

Q. D. Clarkson

APPROVED:

ElfP Fisher, Jr., Head, Department of Biology

David T. Clark, Dean of Graduate Studies 
TABLE OF CONTENTS

PAGE

ACKNOWLEDGEMENTS

111

LIST OF TABLES $\ldots \ldots \ldots \ldots \ldots \ldots \ldots \ldots \ldots \ldots \ldots \ldots \ldots \ldots \ldots \ldots \ldots$

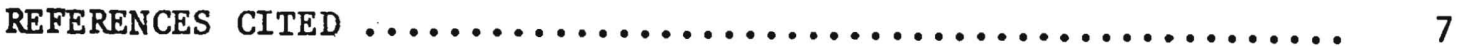

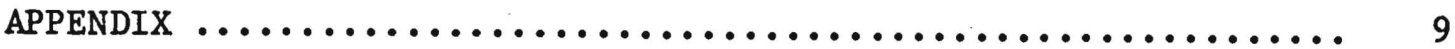




\section{ACKNOWLEDGEMENTS}

I thank Dr. Richard Forbes, Dr. Richard Petersen, and Dr. Q. D. Clarkson for commentary, guidance and counsel during the course of this project; Dr. Earl Fisher and the Biology Department at Portland State University for equipment and material assistance; Dr. Marvin Beeson and Larry Seebler for technical assistance; and Jeanne Raymond for financial and moral support. 


\section{LIST OF TABLES}

TABLE

I Lead content of hair samples of various populations of small mammals $\ldots \ldots \ldots \ldots \ldots \ldots \ldots \ldots \ldots \ldots \ldots \ldots \ldots$

II Percent of animals with lead in hair greater than 30.00

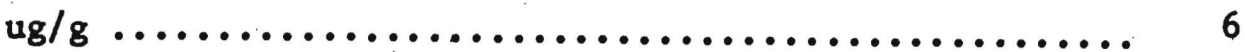


Since 1940 there has been a rapid increase in the amount of lead dispersed in the environment $(1,2)$. This tacrease has been attributed largely to lead aerosols that result from the burning of alkyl lead compounds in gasoline $(3,4)$. Concentrations of lead in city air and in precipitation are correlated with the amount of automotive traffic $(5,6)$. Rapid fallout of lead along heavily traveled roads results in a high exposure of the nearby plants and soil to lead; exposure to lead diminishes rapidly as distance from the road increases $(7,8)$. Chow (9), and Motto et al. (10), found that plants growing close to heavily trave1ed roads show elevated levels of lead, and that these levels are dependent on proximity to the road. Smith (11) found also that the amount of lead in plant tissues is related to proximity to highways, and to traffic volume.

In order to investigate the effects of increased risk of exposure to high lead levels for roadside organisms, I measured the amounts of lead In hair of small mamnals (Sorex sp., Peromyscus maniculatus, Eutamias townsendi1, and Microtus $\mathrm{sp}_{\text {.) }}$ from urban and rural populations. Hair has been shown to be useful indicator of body burden of lead $(12,13)$. It is easy to obtain, and since $1 . t$ is exposed to the aix it can also give an indication of total exposure. I found that members of roadside small mammal populations had significantly higher levels of lead in their hair than did members of either urban parkland or wilderness populations. In contrast to a study by Weiss et al. (14) on human hair, I found no signtficant difference between lead content of the hair of mammals trapped in 1972, and those trapped in similar habitats 60 years ago. 
Animals were trapped in three locations; "roadside" specimens beside US highway 26, a heavily traveled road $(66,500$ vehicles per day) onehalf mile west of downtown Portland, Oregon; "parkland" specimens in Forest Park, an urban wildlife preserve about one-half mile from the nearest traveled road (18,000 vehicles per day) in Portland, Oregon; and "wilderness" specimens in the Mt. Hood National Forest (T. 4 S., R. 8 E., Clackamas County, Oregon) two miles from the nearest road access, and five miles from US highway 26 , the nearest major road. Locations were selected to be as similar in plant cover and topography as possible. Antique hair was obtained from study skins of small mammals trapped in the Northwestern area of Oregon between 1913 and 1915.

The analytical method used was that of Harrison et al. (15). Each hair sample was divided into two parts. One part was washed by agitation in a solution of $1 \%$, nonionic detergent (16) for 30 minutes, then thoroughIy rinsed in a polyethylene filter funnel with a total of 1 liter of delonized-distilled water. All of the samples were dried at $110^{\circ} \mathrm{C}$ to constant weight, weighed to the nearest $0.1 \mathrm{mg}$, , and digested in nitric and perchloric acid $(5: 1)$. The digests were evaporated to dryness, and diluted to $10 \mathrm{ml}$ in volumetric flasks with deionized-distilled water. Analysis for lead was done with a Perkin-Elmer 303 atomic absorbtion spectrophotometer according to the manufacturer's instructions. Duplicate samples were analyzed, as well as reagent blanks and standards. The primary lead standard was a 10,000 ug/ml stock solution from Instrumentation Laboratory Inc.

The data in Table I show the amounts of lead found in hair of the mammals examined. When the samples were compared between groups by a $t$ test, the roadside specimens showed amounts of lead in hair significantly 
higher $(P<.001)$ than those in the other three groups, both in washed and unwashed samples. The amounts of lead found in unwashed parkland samples were also higher $(P<.05)$ than in unwashed wilderness samples. The unwashed hair samples from the roadside and antique groups had significantly higher lead content $(\mathrm{P}<.01)$ than the washed samples from the same animals. The difference between washed and unwashed samples for park animals was not significant ( $P>.20)$, and no difference could be detected for animals trapped in the wilderness.

Tentative signs of lead poisoning may be observed in humans having amounts of lead as low as $30 \mathrm{ug} / \mathrm{g}$ in their hair (13). Table II shows the percent of animals in each group whose hair showed lead amounts greatèr than $30 \mathrm{ug} / \mathrm{g}$.

My results indicate that the high exposure to lead for small mammals living near a heavily traveled road results in a significantly increased amount of lead in the hair. There apparently is less exposure to lead at an uxban site removed from the roads, but even this is marked1y higher than the exposure to lead of animal relatively isolated from contact with automobile exhausts. Despite higher exposure of contemporary wild small mammals to lead, there seems to be no greater amount of lead present in their hair than in that of such mammals trapped before the introduction of lead anti-knock compounds into gasoline. This is in contrast to data from studies on Swedish moss (17) that showed a chronological increase in lead content presumably related to use of akyl lead compounds in gasoline, and to studies on human hair (14) and bones (2) which showed a decrease in lead content from 1871 to the present, possibly related to decreased exposure from paint and household utensils. 
Schroeder $(18,19)$ has shown that lifelong exposure to lead, resulting in lead levels similar to those found in humans has an adverse effect on survival of mice and rats of any age, and that lead seems to be continuously toxic, increasing susceptibility of rats to spontaneous infection. My results indicate that near heavily traveled roads the levels of lead to which small mammals are exposed may be great enough to affect detrimentally their health and longevity. 
TABLE I.

LEAD CONTENT OF HAIR OF VARIOUS POPULATIONS

OF SMALL MAMMALS (Mean $\pm s t a n d a r d$ error)

Group

Roadside

Parkland

W11derness

Antique

Lead (ug/g dry weight)

Washed

$133.08 \pm 21.31$

$11.16 \pm 3.22$

0

$17.72 \pm 4.30$
Unwashed

$235.63 \pm 36.80$

$25.05 \pm 6.69$

$6.02 \pm 2.27$

$29.89 \pm 8.62$ 
TABLE II.

PERCENT OF ANIMALS WITH LEAD IN HAIR GREATER THAN $30.00 \mathrm{ug} / \mathrm{g}$

Group

Percent

\begin{tabular}{cc}
\hline Washed & Unwashed \\
\cline { 2 - 2 } 65.85 & 92.68 \\
0 & 21.43 \\
0 & 0
\end{tabular}

Antịque

11.76

41.18 
1. Jenkins, Dale W., "The Toxic Metals in Your Future--and Your Past", Smithsonian 3(1):62-69, 1972 .

2. Jaworowski, Z., "Stable Lead in Fossil Ice and Bones," Nature, 217: 152-153, 1968.

3. Chow, T. J., and J. L. Earl, "Lead Aerosols in the Atmosphere: Increasing Concentrations," Science 169:577-580, 1970.

4. "Airborne Lead in Perspective," Nat. Acad. Sci. Nat. Res. Counc. Pub1. No. 1941 (1972), p. 12.

5. Bove, J. L., and S. Siebenberg, "Airborne Lead and Carbon Monoxide at 45th Street, New York City," Science 167:986-987, 1970.

6. Lazrus, A. L., E. Lorange, J. P. Lodge Jr., "Lead and Other Metal Ions in United States Precipitation," Env. Sci. and Tech. 4:56-58, 1970.

7. Patterson, C. C., "Contaminated and Natural Lead Environments of Man," Arch. Environ. Health 11:344-360, 1965.

8. Lagerwerff, J. V., and A. W. Specht, "Contamination of Roadside Soil and Vegetation with Cadmium, Nickel, Lead, and Zinc," Env. Sci. Tech. 4; 583-583. 1970 .

9. Chow, T. J., "Lead and Mercury Burden of Urban Woody Plants," Science $176: 1237-1239,1972$.

10. Motto, H. L., R. H. Daines, D. M. Chilko, C. K. Motto, "Lead in Soils and Plants: Its Relationship to Traffic Volume and Proximity to Highways," Env. Sc1. Tech. 4:231-238, 1970.

11. Smlth, W. H., "Lead and Mercury Burden of Urban Woody Plants," Science 176:1237-1239, 1972 .

12. Hammer, D. I., J. F. Finklea, R. H. Hendricks, C. M. Shy, R. J. M. Horton, "Hair Trace Metal Levels and Environmental Exposure," Amer. J. Epidemiol. 93:84-95, 1971.

13. Kopito, L., M. S. Randolph, K. Byers, H. Shwachman, "Lead in Hair of Children with Chronic Lead Poisoning", New Eng1. J. Med., 276:946-953, 1967.

14. Weiss, D., B. Whitten, D. Leddy, "Lead Content of Human Hair (18711971)" Science, 178:69-70, 1972.

15. Harrison, W. W., J. P. Yurachek, C. A. Benson, "The Determination of Trace Elements in Human Hair by Atomic Absorption Spectroscopy", Clin. Chim. Acta, 23:83-91, 1969. 
16. Acationix, Scientific Products, Evanston, Illinois

17. "Airborne Lead in Perspective" p. 7.

18. Schroeder, H. A. et al. "Chromium, Cadmuim, and Lead in Rats: Effects on Life Span, Tumors, and Tissue Levels," J. Nutr., 86:51-66, 1965.

19. Schroeder H. S., et al. "Chromium, Lead Cadmium, Nickel and Titanium in Mice: Effect on Mortality, Tumors, and Tissue Levels", J. Nutr. 83:239-250, 1964 . 


\section{APPENDIX}

This study was originally designed as a nested sample, to be analyzed by a hierarchical analysis of variance. During the course of the study several events transpired to make this type of analysis inadvisable. Individuals to be tested were sampled from two areas within each of three locations. However, because of differential trapping success, the samples drawn were of unequal sizes, leading to an unbalanced design. Unequal sample size does not preclude treatment by ANOVA, but does make it more difficult, and tends to decrease the frequency of detecting a difference in sample means.

After the study began, data were gathered from sample groups not incorporated into the original design. These sample groups proved to be from populations which had greatly differing variances. A requirement of ANOVA is that samples be from populations with equal variances. Additional difficulties, not related to the statistical method, included lack of a pilot study (the appropriate analytical methods were not available), the small size of some sample groups, and the variability due to the analytical method (because of the small amounts of material analyzed I found I was working at the limits of detection of atomic absorbtion analysis).

The results were finally analyzed by a $t$ test to determine a difference between means of groups with differing variances. This test was done on groups felt to provide the most interesting comparisons. I believe the results obtained and conclusions drawn are valid, and are consistent with my data. However, to try to say more, or find additional significant results, would be taxing the data to an unjustified extent. 